Diabetologia 11, 285-289(1975)

(C) by Springer-Verlag 1975

\title{
Ultrastructural Changes of the Endocrine Pancreas in Pregnant Rats*
}

\author{
L. Aerts, and F.A. Van Assche \\ Laboratory of Gynecological Physiopathology, Department of Obstetrics and Gynecology (K.U.L.), Academisch Ziekenhuis St. Rafaël, \\ Leuven, Belgium
}

Received: January 20, 1975, and in revised form: May 5, 1975

Summary. The ultramicroscopic appearence of the B-cell of the pregnant rat suggests hyperinsulinism of the individual beta cell. In pregnant rats the B-cell contains an increased volume and an increased number of light granules as well as enlarged mitochondria.
Key-words: Ultrastructure, pregnancy, B-cell, granule type, light (pale) granules, dark granules.
In a previous quantitative morphologic study [1], we have shown a marked hypertrophy of the islets of Langerhans in pregnant rats; this islet hypertrophy is mainly due to hyperplasia of the B-cells. Our findings supported the data of Green and Taylor [2], who found that rat islets not only are larger in pregnancy, but possess a more sensitive mechanism for responding to glucose and other secretagogues.

In order to have some idea of what the changes are in the B-cell itself in the pregnant rat, we began a study of the ultramicroscopic aspects including quantitation, using morphometric techniques applied to electron microscopy.

\section{Material and Methods}

Five pregnant and five non-pregnant female albino rats of comparable age and weight that had never been pregnant before were studied. The pregnant rats had been caged overnight with males and afterwards isolated if the copulation plug had been present: this day was considered as day 1 of gestation. The animals had food and water ad libitum. The pregnant rats were killed at day 20 of gestation at the same hour (2 p.m.) as the control group. Unselected pieces of pancreas were removed and immediately fixed for $2 \mathrm{~h}$ in glutaraldehyde $25 \%$ and paraformaldehyde $4 \%$ (6:19) in cacodylate buffer. Postfixation was done with OsO4 1\% in phosphate buffer for $1 \mathrm{~h}$. The tissue was dehydrated in graded alcohols, embedded in epon

\footnotetext{
* This study was supported by grant nr. 20.334 „Fonds voor Geneeskundig Wetenschappelijk Onderzoek."
}

and sectioned with glass knives on a LKB ultramicrotome. The sections $( \pm 700 \AA)$ were placed on 200 mesh copper grids, stained with uranyl acetate and lead citrate, and examined in a Zeiss EM 9 S-2.

Thirty islets ( 6 from each rat) were studied from each group. From each islet 2 electron-micrographs were taken at an original magnification of $4.800 \mathrm{x}$. Random sampling of the micrographs was achieved by using the same corner of the chosen square of the copper grid. Standard stereologic procedures [3] were used to estimate the volume density and the numerical density of the beta granules and the volume density of the mitochondria in the B-cells. The volume density of the secretory material in the granules was also estimated. The volume density of the organelles was calculated by the method of point counting by placing a lattice of 144 points, separated in the $X$ and $Y$ direction by $1.5 \mathrm{~mm}$ (original magnification). The results were expressed in terms of the volume percentage of the organelle $\left(V_{O}\right)$ to the total volume of the B-cell $\left(V_{T}\right)$, according to the equation $\frac{P_{O}}{P_{T}}=\frac{V_{O}}{V_{T}}$. $P_{O}$ is the points counted on the organelle; $P_{T}$ is the total of points on B-cell tissue. The numerical density of the granules $\left(N_{V} G\right)$ in the B-cell tissue was estimated from counts of granule profiles in a test area of $324 \mathrm{~mm}^{2}$ on each micrograph (original magnification) and calculated by using the equation $N_{V} G=$ $\frac{K}{\beta} \cdot \frac{N_{A} G 3 / 2}{V_{V} G 1 / 2}$ where $N_{A} G$ is the number of counted granules in the test area, $V_{V} G$ is the volume density of the granules; $K=1.07$ (25\% variation in 
granule size) and $\beta=1.33$ (spherical appearance of the granules). The numerical density of the granules is expressed in terms of number of granules per $\mathrm{mm}^{3}$ of B-cell tissue. The mean diameter $(\bar{D})$ of the granules was calculated using the equation $\bar{D}=\frac{N_{A} G}{N_{V} G}$.

We counted the volume density of the granules $\left(V_{V} G\right)$, the volume density of the secretory content of the granules $\left(V_{V} S G\right)$, the numerical density of the granules $\left(N_{V} G\right)$ and the mean diameter $(\bar{D})$ of the granules. We also counted the volume density of the mitochondria. Quantitation of other features such as Golgi vesicles and the numerical density of mitochondria were impracticable because of the frequent bizarre shapes of these organelles.

\section{Results}

\section{Qualitative Aspects}

We can clearly distinguish in the pancreatic B-cells of the pregnant, as well as of the non-pregnant rats, two different types of beta-granules: the dark beta granules (DG) with an electron dense core and a broad white halo, and the light (pale) beta-granules
(LG) with an electron lucent core and a narrow white halo. Exceptionally we have seen intermediate forms (Figs. 1 and 2).

We have observed that both dark and light (pale) granules can be located close to the cell membrane (Fig. 3).

The number of light granules is markedly increased in the pregnant group (Fig. 1 and 2).

Observations of A and D cells reveal no striking differences between the non-pregnant and the pregnant rats.

\section{Quantitative Aspects}

Table 1 shows that the volume density of the dark granules $\left(V_{V} D G\right)$ and the volume density of the secretory content of the dark granules $\left(V_{V} S D G\right)$, occupying $1 / 3$ of the granule, are the same in pregnant and non-pregnant rats.

No difference is also found in the numerical density and the diameter of the dark granules. In the non-pregnant group the dark granules occupy 80.5 per cent of the beta-granule population, in the pregnant group only 67 per cent.

The volume density of the light granules $\left(V_{V} L G\right)$ and the volume density of the secretory content of the light granules $\left(V_{V} S L G\right)$, occupying $2 / 3$ of the granule

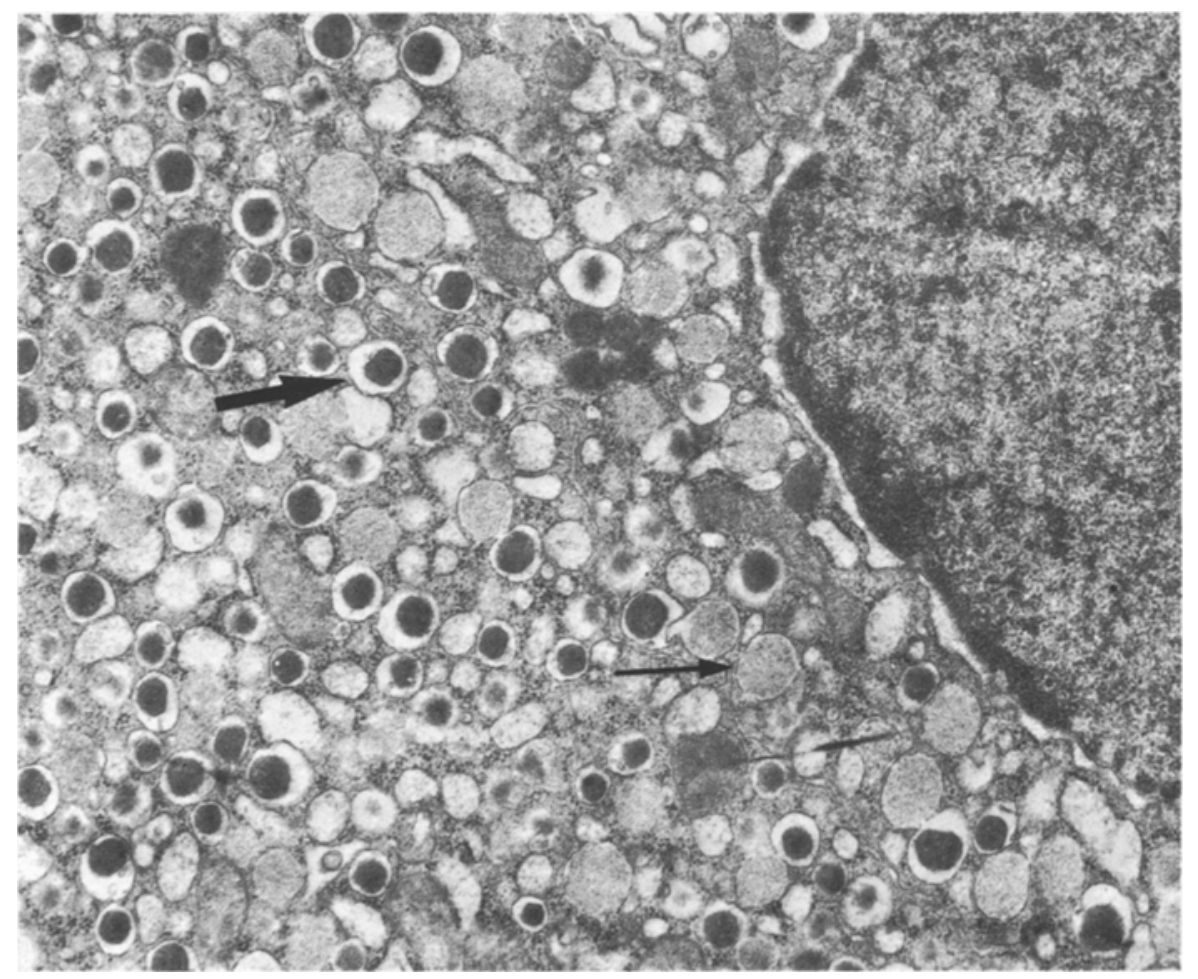

Fig. 1. B-cell of a non-pregnant rat. Dark granule, heavy arrow; light granule, thin arrow $\mathrm{Em} \times 16.800$ 


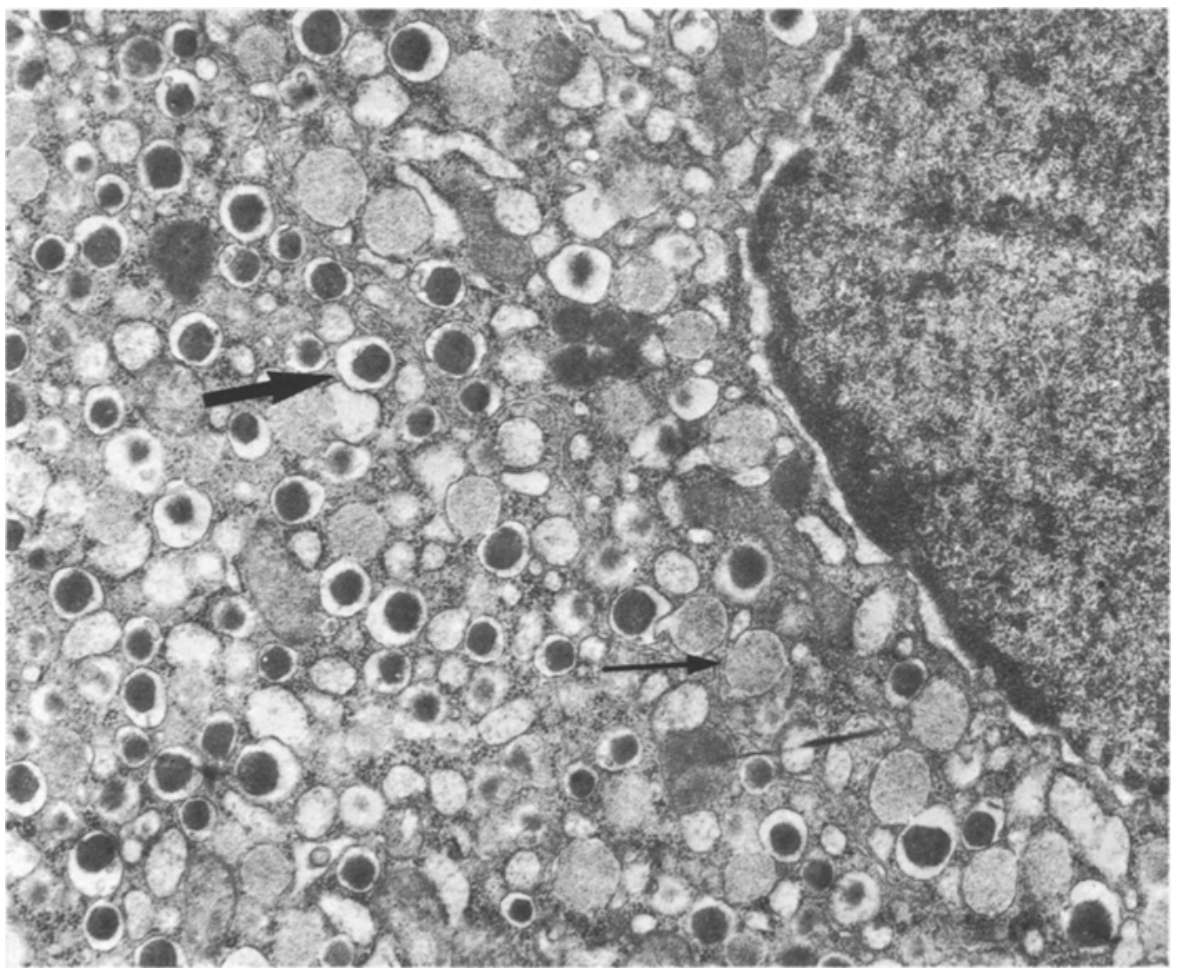

Fig. 2. B-cell of a pregnant rat. Increased number of light granules (cfr. Fig. 1). Intermediate granule arrowed $\quad$ Em $\times 16.800$

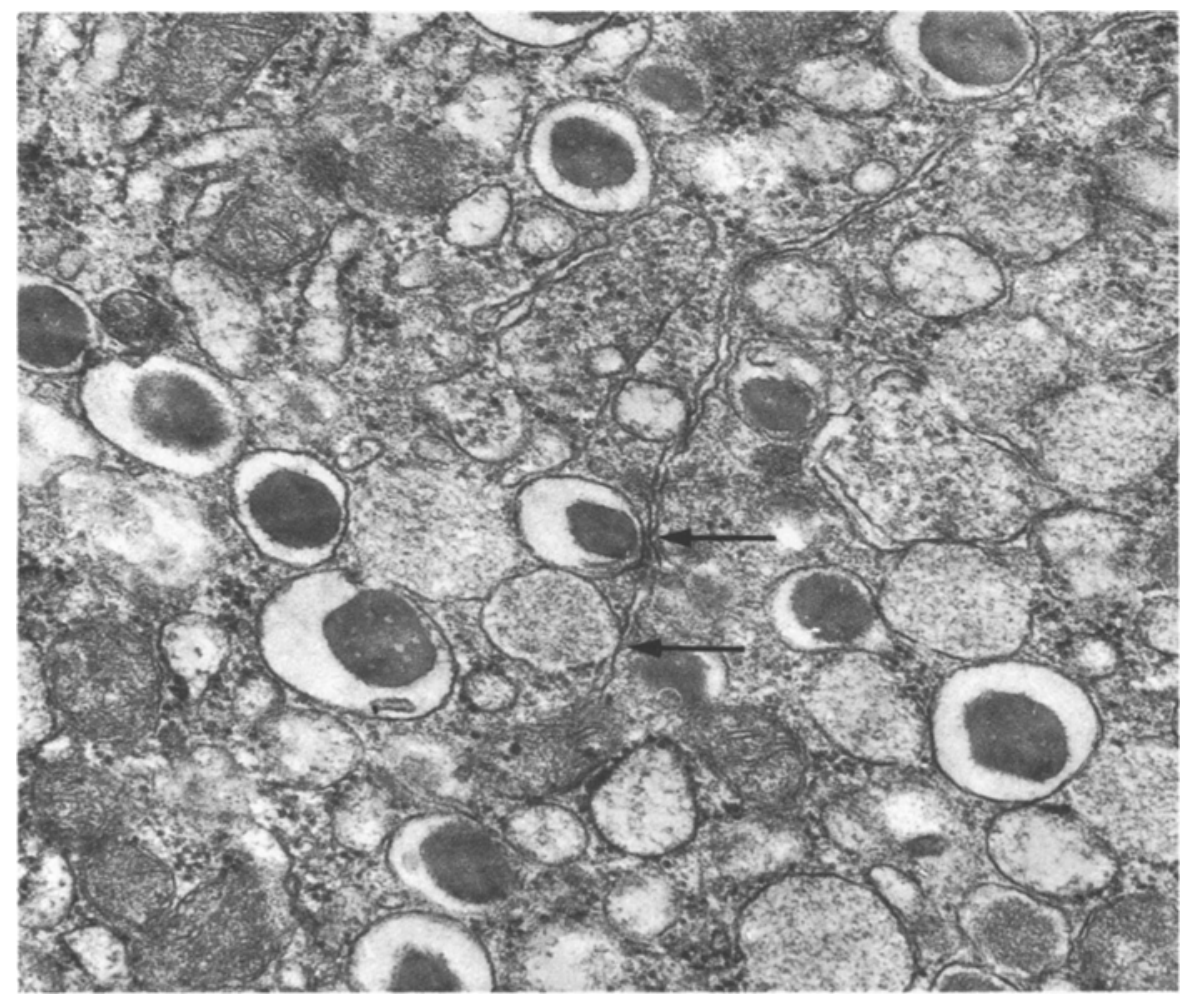

Fig. 3. Light (pale) granules and dark granules in a B-cell located close to the cell membrane $\operatorname{Em} \times 33.250$ 
Table 1. Morphometric data of the dark granules (Mean \pm S.D.)

\begin{tabular}{lllll}
\hline & $\begin{array}{l}\text { Volume density of } \\
\text { dark granules } \\
\left(V_{\nu} D G\right)^{a}\end{array}$ & $\begin{array}{l}\text { Volume density of } \\
\text { secretory content of } \\
\text { dark granules } \\
\left(V_{\nu} S D G\right)^{a}\end{array}$ & $\begin{array}{l}\text { Numerical density } \\
\text { of dark granules } \\
\left(N_{\nu} D G\right) \\
\text { per mm }\end{array}$ & $\begin{array}{l}\text { Mean diameter of } \\
\text { dark granules } \\
(\bar{D} D G) \\
\mu\end{array}$ \\
\hline Non pregnant & $14.82 \pm 3.52$ & $4.88 \pm 1.06$ & $3.711 \times 10^{6}$ & $0.4046 \pm 0.0224$ \\
Pregnant & $13.90 \pm 2.87$ & $4.46 \pm 0.68$ & $\begin{array}{l} \pm .848 \times 10^{6} \\
\pm 299 \times 10^{6}\end{array}$ & $0.4366 \pm 0.0233$ \\
P & N.S. & N.S. & N.S. & N.S. \\
\hline
\end{tabular}

a expressed in per cent of total B-cell volume

Table 2. Morphometric data of the light granules (Mean \pm S.D.)

\begin{tabular}{|c|c|c|c|c|}
\hline & $\begin{array}{l}\text { Volume density of } \\
\text { light granules } \\
\left(V_{V} L G\right)^{a}\end{array}$ & $\begin{array}{l}\text { Volume density of } \\
\text { secretory content } \\
\text { of light granules } \\
\left(V_{V} S L G 7^{a}\right.\end{array}$ & $\begin{array}{l}\text { Numerical density of } \\
\text { light granules } \\
\left(N_{V} L G\right) \\
\text { per } \mathrm{mm}^{3}\end{array}$ & $\begin{array}{l}\text { Mean diameter of } \\
\text { light granules } \\
(\bar{D} L G) \\
\mu\end{array}$ \\
\hline Non pregnant & $4.20 \pm 1.15$ & $2.82 \pm 0.98$ & $915 \times 10^{6} \pm 101 \times 10^{6}$ & $0.4214 \pm 0.0130$ \\
\hline $\begin{array}{l}\text { Pregnant } \\
\mathrm{P}\end{array}$ & $\begin{array}{l}8.02 \pm 2.18 \\
<0.005\end{array}$ & $\begin{array}{l}5.56 \pm 1.52 \\
<0.005\end{array}$ & $\begin{array}{l}1406 \times 10^{6} \pm 103 \times 10^{6} \\
<0.005\end{array}$ & $\begin{array}{l}0.4552 \pm 0.0207 \\
\text { N.S. }\end{array}$ \\
\hline
\end{tabular}

${ }^{\text {a }}$ expressed in per cent of total B-cell volume

volume, is significantly increased in the pregnant group. The number of light granules $\left(N_{V} L G\right)$ is also increased in the pregnant group. The mean diameter of the light granules remains unchanged (Table 2). In the pregnant group the light granules occupy 33 per cent of the beta-granule population compared with 19.5 per cent in the non-pregnant group. The volume density of the mitochondria is slightly increased in the pregnant group (Table 3 ).

Table 3. Morphometric data of the mitochondria (Mean \pm S.D.)

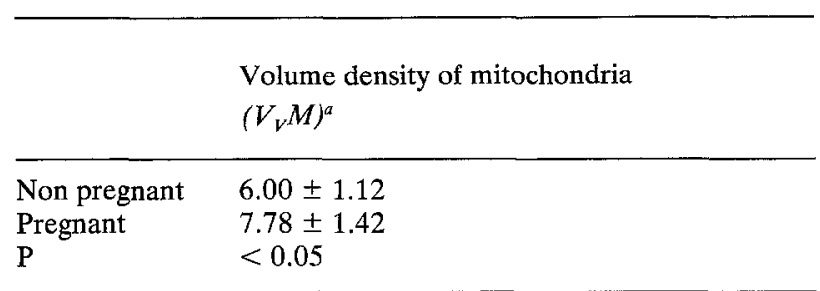

${ }^{a}$ expressed in per cent of the total B-cell volume

\section{Discussion}

This ultramicroscopic quantitative study shows that in pregnant rats the B-cell contains an increased volume and an increased number of light (pale) granules. We also find enlarged mitochondria. It is known that with glutaraldehyde fixation light and dark granules are observed in man and rat $[4,5,6,7,8,9$, $10,11,12,13]$. The difference in electron density of the secretory material might be due to a different chemical or physical form of insulin [8]. It could also be due to a difference in the structure of the lipoprotein carrier to which insulin is bound in the beta-granule [11]. Goldenberg et al. [5] and Moleson et al. [9] consider the light granules as immature precursors of the mature dark granules. However, Howell et al. [6] have shown, using labelled amino-acids, that tracing appears at the same time in the dark and the light granules. This suggests that the light granules are probably not the precursors of the dark granules.

We have previously shown that islet hypertrophy and B-cell hyperplasia exist in the rat during pregnan- 
cy. These morphologic findings correlate with hyperinsulinism in animal and human pregnancies [1]. Green and Taylor [2] have found that rat islets during pregnancy have a more sensitive mechanism for detecting and responding to glucose and other secretagogues.

In the individual B-cell during pregnancy an increased volume and an increased number of the total granule population is present, due to an augmented volume density and an augmented numerical density of the light (pale) granules. Moreover, there is an increased volume density of the mitochondria in the B-cell. The more pronounced granulation of the B-cell during pregnancy is at variance with the calculation of Green and Taylor [2] that the amount of insulin is not increased in the B-cell of the pregnant rat.

The dark as well as the light (pale) granules can be located close to the cell membrane. Nakayama et al. [10] and Shino et al. [13] have postulated that the light granules are responsible for the immediate, active release of insulin, while the dark granules represent the insulin reserve in the B-cell. However, since there is controversy concerning the functional role of the light granules $[5,6,9,10,11,13,14]$, it is not possible to draw any conclusion concerning enhanced insulin release of the individual B-cell during pregnancy.

Acknowledgements. We thank Prof. W.B. Robertson, Prof. Renaer, Prof. Brosens and Dr. C. Dewolf-Peeters for their stimulating advice and also M. R. Puttemans and M.C. Smedts for technical help and Kris Meyhi who typed the manuscript.

\section{References}

1. Van Assche, F.A.: Quantitative morphologic and histoenzymatic study of the endocrine pancreas in non-pregnant and pregnant rats. Amer. J. Obstet. Gynec. 118, 39-41 (1974)
2. Green, I.C., Taylor, K.W.: Effect of pregnancy in the rat on the size and insulin-secretory-response of the islets of Langerhans. J. Endocr. 54, 317-325 (1972)

3. Weibel, E.R.: Stereological principles for morphometry in electron microscopic cytology. Int. Rev. Cytol. 26, 235-303 (1969)

4. Deconinck, J.F., Potvliege, P.R., Gepts, W.: The ultrastructure of human pancreatic islets. I. The islets of adults. Diabetologia 7, 266-282 (1971)

5. Goldenberg, V.E., Goldenberg, N.S., Benditt, E.P.: Ultrastructural features of functioning alpha and beta-cell tumors. Cancer 24, 236-247 (1969)

6. Howell, S. L., Kostianovsky, M., Lacy, P.E.: Beta-granule formation in isolated islets of Langerhans. A study by electron microscopic radioautography. J. Cell Biol. 42, 695-705 (1969)

7. Hultquist, G., Ponten, J.: Ultrastructure of rat pancreatic islets in long term tissue culture. Upsala J. Med. Sci. 79, 21-27 (1974)

8. Like, A.A.: The ultrastructure of the secretory cells of Langerhans in man. Lab. Invest. 16, 937-941 (1967)

9. Moleson, A.D., Moses, J.M., Hackel, D.B.: Protein synthesis in pancreatic beta-cells of the normal diabetic Egyptian sand-rat. An autoradiographic study with the electron microscope. Amer. J. Path. 73, 495-512 (1973)

10. Nakayama, I., Takaharo, O., Tsuchiyama, H.: An ultrastructural study of synthesis and release of beta-granules in the human pancreas. Acta path. jap. 21, 321-347 (1971)

11. Petkov, P., Danen, S.: The problem of granule-ultrastructure in the endocrine pancreas. Acta diabet. lat. 10, 54-88 (1973)

12. Renold, A.E.: The beta-cell and its responses. Diabetes 21 (suppl. 2), 619-631 (1972)

13. Shino, A., Matsuo, T., Iwatsuka, H., Suzuoki, Z.: Structural changes of pancreatic islets in genetically obese rats. Diabetologia 9, 413-421 (1973)

14. Gomez-Acebo, J., Garcia, Hermida, O.: Morphological relations between rat secretory granules and the microtubular microfilament system during sustained insulin release in vitro. J. Anat. (Lond.) 114, 421-437 (1973)

Prof. Dr. F.A. Van Assche

Dept. of Obstetrics and

Gynecology (K.U.L.)

Academisch Ziekenhuis

Sint Rafael

Kapucijnevoer

B-3000 Leuven

Belgien 